\title{
Mechanism of development of coal dust continuous explosion in a network of mine workings
}

Rudarsko-geološko-naftni zbornik

(The Mining-Geology-Petroleum Engineering Bulletin) UDC: 622.817

DOI: $10.17794 / \operatorname{rgn} .2022 .1 .5$

Original scientific paper

\author{
Viktor Kostenko', Olena Zavialova', Serhii Pozdieiev'², Tetiana Kostenko², Viktor Hvozd ${ }^{2}$ \\ ${ }^{1}$ Donetsk National Technical University, 2, Shybankova Square, Pokrovsk, Donetsk region, 85300, Ukraine. \\ ${ }^{2}$ Cherkasy Institute of Fire Safety named after Chornobyl Heroes of National University of Civil Defence of Ukraine, 8, Onoprienka Street, \\ Cherkasy, 18034, Ukraine.
}

\begin{abstract}
The objective of this paper is to reveal the mechanism of creating conditions for the continuous explosion of coal dust by transferring seismic energy to coal dust located along the perimeter of a working. The ANSYS software package was used to model the movement of coal dust particles in the air under the influence of seismic waves caused by the action of an explosion. It was confirmed by modelling that seismic waves, provoked by an explosion, propagate in the rock mass at a higher velocity than the moving explosive front in the air of a working. The qualitative and quantitative behaviour of a layer of coal dust in the process of oscillation of the working walls under the influence of seismic waves during one second was described. The stage of dynamic loosening of the powder is supplemented by the initial period of the mechanism of explosion development, when there are no combustible concentrations of gas or coal traces in the air composition of the mine working before the incident. It is established that under the seismic influence at a distance of about $50 \mathrm{~m}$ from the hypocentre of the explosion, a layer of powder-like dispersed coal rises into the air forming a dust cloud, which is the initiator of further continuous development of the explosion spreading in a network of mine workings.
\end{abstract}

Keywords:

explosion; coal dust; modelling; seismic waves; mine workings

\section{Introduction}

Explosions of air-methane mixtures, as well as air-coal dust mixtures, in the mine workings are the most severe types of accidents in terms of number of victims and financial loss. From 1990 to 2013 (before the start of hostilities in Donbas), the largest number of injuries in the coal mines of Ukraine ( $65 \%$ of total injuries and $58 \%$ of fatalities) was caused by gas and dust explosions (Kostenko et al., 2021). Unfortunately, underground coal producers are faced with explosions around the world. The situations where the blast wave travelled in a network of workings over long distances, sometimes for several kilometres, with no flammable gases or dust in the air, are characterized by particularly severe consequences. Therefore, the characterization of the peculiarities of the mechanism of explosive front development in the workings, where no conditions for the combustion of aerosols exist, is of urgent scientific and technical importance.

Unlike the mixtures of flammable gases or vapours with air, which are usually quasi-stable and tend to occupy the entire available space, the air-dust suspension is an unstable, inhomogeneous system, where solid par-

Corresponding author: Tetiana Kostenko

tatiana.kostenko@gmail.com ticles settle over time and at different distances, depending on their weight. In particular, the flammability of aerosols depends on additional factors related to the physical and chemical properties of combustible solids, the shape and size of dust particles, as well as the environmental conditions where dust exists as a suspension (Prodan et al., 2017).

The analysis of data on the ignition (explosion) of coal dust was performed using a 20 litre explosive chamber. The results showed that the maximum explosion pressure and the rate of pressure increase are achieved at a coal dust concentration of $100 \mathrm{~g} / \mathrm{m}^{3}$. For the coal grades under study, the maximum pressure was 0.7 to $0.8 \mathrm{MPa}$, and the rate of pressure increase was $43-50 \mathrm{MPa} / \mathrm{s}$. It was proven that the size of the particles of the coal dust sample of 63-94 $\mu \mathrm{m}$ was the most dangerous (Zhikharev et al., 2018).

The process of combustion of fine dusted mixtures of combustible gases in the diffusion region was reviewed. A boundary value problem for a second-order differential equation, which takes into account convection mass transfer in addition to molecular diffusion, was formulated. The resulting formula determines the length of the combustion zone, with the plots varying depending on the parameters of dusted mixtures of combustible gases (Cherdantsev et al., 2020). 
The steady-state process of ignition of micro-heterogeneous dust-air mixture in underground workings is reviewed. The critical ignition temperature of mixtures was determined, and the mechanisms of influence of some mixture parameters on the ignition temperature were identified (Cherdantsev et al., 2018).

Studying many articles on coal explosions, it was found that humidity is an important parameter in coal explosion capability (Moradi et al., 2020). The effect of this parameter was investigated on the predictability of coal dust explosions. Using a regression analysis method, a model was presented to predict the explosion index based on the moisture parameters.

Among the numerous mechanisms responsible for flame acceleration, such as combustion instability, turbulence, acoustics and friction against the walls, the acceleration of the flame front in the form of a protuberance is of significant importance in coal mines, since the mechanism is a scale-invariant one, and therefore it does not depend on the Reynolds number. It was demonstrated that gas compression in general slows down the acceleration of the flame, and its effect depends on various thermochemical parameters (Demir et al., 2017).

The experimentation work was carried out in an explosive chamber of cylindrical shape, made of low-carbon steel, $30 \mathrm{~m}$ long and $0.5 \mathrm{~m}$ in diameter. Methane and coal dust were used as fuel, and chemical igniters with known energy were used for ignition. The results demonstrated that both the ignition energy and the dust concentration significantly affect the overall pressure ratio (OPR) in the explosion chamber. OPR was doubled when $30 \mathrm{~g} / \mathrm{m}^{3}$ of coal dust was added to $6 \%$ of the methane-air mixture, and it increased by $60 \%$ when the ignition source of $10 \mathrm{~kJ}$ was used instead of $1 \mathrm{~kJ}$. The maximum flame front velocity observed for the ignition source with an energy of 5 kJ was twice the flame front velocity for the ignition source of $1 \mathrm{~kJ}$. The time required for the initial ignition of methane was reduced by approximately $50 \%$ when using the ignition source of $10 \mathrm{~kJ}$ instead of the ignition source of $1 \mathrm{~kJ}$ (Ajrash et al., 2016).

Combustion, explosion and detonation in hybrid systems containing gas mixtures, such as $\mathrm{CH}_{4} /$ air, $\mathrm{CH}_{4} / \mathrm{O}_{2}$ and $\mathrm{O}_{2} /$ coal particles up to $200 \mu \mathrm{m}$ in size and an average bulk density of up to $700 \mathrm{~g} / \mathrm{m}^{3}$, are studied in an ignition percussion tube with a vertical axis. It has been demonstrated that in hybrid systems, coal dust has less effect on the parameters of combustion and detonation waves than methane, and that methane is more reactive in such waves than coal dust is (Pinaev et al., 2020).

In the standard $20 \mathrm{~L}$ range, the maximum explosion pressure, explosion index and lower explosive limits of mixtures of methane and coal dust were measured. The results demonstrate that the addition of methane to various types of coal dust clearly increases the maximum explosion pressure and explosion index, while reducing the minimum explosive concentration. The effect of methane on the force of the explosion is more pro- nounced for coal dust with a low volatile content, and on the sensitivity to ignition - for coal dust with a higher volatile content (Wang et al., 2020).

To study the pressure law of a hybrid explosion of gas-coal dust in a semi-enclosed vertical space, a system of vertical pipelines, consisting of an explosion chamber, a propagation pipeline and auxiliary equipment, was used. Coal dust with concentrations of 25, 50, 100 and $200 \mathrm{~g} / \mathrm{m}^{3}$, and particle sizes of 45, 75, 106 and $150 \mu \mathrm{m}$, was enriched with gas with a concentration of $9 \%$. The maximum rate of pressure increase in the propagation pipeline increases with decreasing particle size of coal dust. When using coal dust with a concentration of $50 \mathrm{~g} /$ $\mathrm{m}^{3}$, the maximum explosion pressure reaches its highest value. Coal dust with a concentration of $200 \mathrm{~g} / \mathrm{m}^{3}$, had an obvious inhibitory effect during a hybrid explosion (Jing et al., 2019).

The effect of particle size and coal dust concentration on the minimum ignition temperature (MIT) of a coal dust cloud was studied in five different ranges of particle sizes: from $<38 \mu \mathrm{m}$, from 38 to $<75 \mu \mathrm{m}$, from 75 to $<212$ $\mu \mathrm{m}$, from 212 to $<425 \mu \mathrm{m}$ and 425 to $<850 \mu \mathrm{m}$. The results demonstrated that the MIT of the coal dust cloud increases exponentially from 420 to $730^{\circ} \mathrm{C}$ with increasing coal dust particle size. The MIT decreases with the concentration of coal dust until a stoichiometric concentration is reached (Mishra et al., 2018).

Using the $20 \mathrm{~L}$ test set-up, the explosive characteristics of gas and coal dust mixtures were studied, and the lower limits of gas explosion and coal dust explosion at different ignition energies, steady-state and turbulent conditions were obtained. As the gas concentration increases, the minimum explosive concentration of the coal dust cloud decreases exponentially, and there is a critical gas concentration, above which the gas plays a leading part in the explosion process. Otherwise, coal dust plays a leading part ( $\mathbf{L i}, \mathbf{2 0 1 8})$.

The formulas were proposed to determine the minimum concentration of dust or drops of sprayed water in the protective cloud and the minimum length of the cloud. The data demonstrate that the dust concentrations and cloud sizes recommended by the standards of the Russian Federation allow to suppress only low-velocity combustion waves, at best (Vasil'ev, 2020).

The fundamental possibility of complete suppression of detonation and combustion by means of a layer consisting of a cloud of inert particles has been experimentally demonstrated. It is recommended to focus on the initial stage of ignition of the methane-air mixture, when it is possible to ensure effective fire area extinguishing with the help of advanced automatic control and management methods considering the strict requirements for space and time (Vasil'ev et al., 2020).

The generalization of the data of the known publications has demonstrated that the formation of explosive conditions in the workings requires the presence of a combustible gas medium with suspended coal. A wide 
range of theoretical studies is devoted to the substantiation of the conditions of the occurrence and development of aerosol explosions and to the study of the dynamics of detonation combustion of hybrid compositions existing in the ventilation flows. However, no research has been found on the disclosure of the mechanism of the formation of explosive mixtures where there are no methane traces in the air, and the coal is found on the walls of the workings and fasteners as a powder.

When conducting experimental studies, it is preferable to use laboratory studies with the conditions when a dust cloud is formed artificially in advance due to ventilation flows or fuel supply to vertical set-ups.

No research has been found on the development of the explosion front known in practice in the workings where there are neither gas traces in the air, nor dust curtains.

When modelling a virtual experimental structure, the mechanism of dissipation of explosion energy in a mine working was taken into account in compliance with geometric and physical criteria of similarity to real-life experimental set-ups (Kostenko et al., 2020). It was found that its significant part propagates in the rock mass. In this case, the velocity of seismic-like waves is much greater than the movement of the blast wave in the cavity of a working. It has been suggested that seismic waves are the source of the transfer of coal dust to a suspended state.

The objective of this paper is to reveal the mechanism of creating conditions for the continuous explosion of coal dust by transferring seismic energy to coal dust located along the perimeter of a working.

To achieve this objective, the following tasks were performed:

- the peculiarities of explosion energy transfer to the initiation of dust cloud formation in the air of a mine working have been studied;

- a mathematical model of the movement of coal dust particles in the air under the influence of seismic waves caused by the action of an explosion has been created;

- the results of modelling the movements of coal particles under the influence of seismic waves as a source of continuous explosion of coal dust have been analyzed.

\section{The peculiarities of explosion energy influence on initiation of dust cloud formation in the air of a mine working}

There are no conditions for the continuous development of an explosion in the absence of dust in the air along the main length of a network of mine workings. With the exception of locations of the formation of finely ground coal from the operation of mining or underground transport vehicles, there is no sufficient concen- tration of dust in the air for the detonation of combustion. However, sad statistics testify to frequent cases of fire front propagation for a distance of several kilometres. Sometimes a shock wave breaks out of the ground to the surface shattering the above-mine structures. This type of accident took place at the Raspadskaya Mine (Mezhdurechensk, Russia ) in 2010 and at the Kirov Mine (Makiyivka, Ukraine) in 2001.

When considering an explosion, it is hypothesized that the initial rise of dust occurs under the influence of rock oscillations, similar to seismic ones. The vibration of rocks gives impulses to coal particles, and as a result, they rise into the air and form a dust cloud. To model this process, a layer of coal deposits along the perimeter of the experimental structure was reviewed, the geometry of this part of the workings is shown in Figure 1.
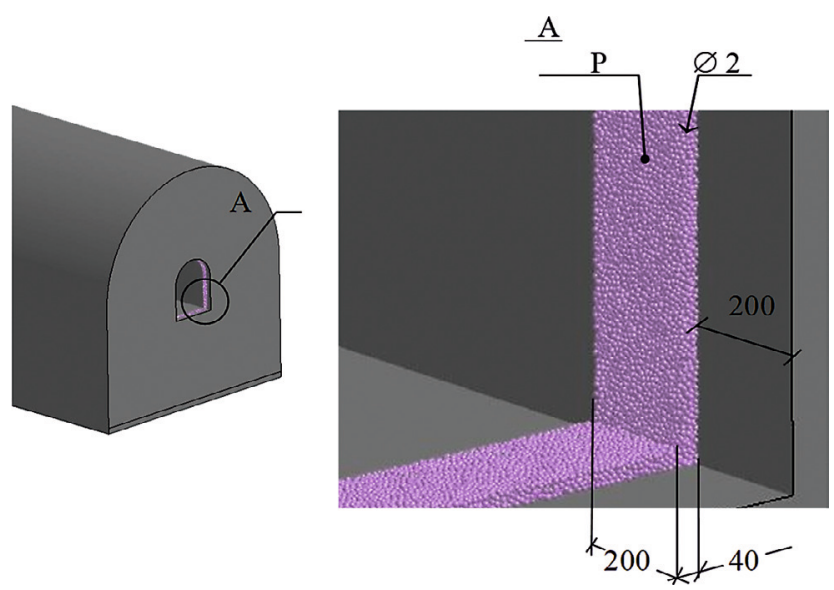

Figure 1: View of the part of the experimental structure with the coal deposits (A) and the parameters of the layer $(\mathrm{P})$ of coal dust

To confirm the validity of the accepted hypothesis, the results of a study of the dynamics of deformation under the action of the explosion of rocks surrounding the mine workings conducted by the authors by means of computer modelling using the finite element method (Kostenko et al., 2020) were used as a basis. When describing the model of coal and dust cover, the following assumptions were made.

1. Only a part of the coal cover $200 \mathrm{~mm}$ wide and 40 $\mathrm{mm}$ thick is considered as an average of data on similar deposits in the coal mine workings. The limited size of the dust load is due to the limited computing power of the computer, and the cumbersome calculations that are required.

2. Dust particles are taken as regular spheres of the same diameter of $2 \mathrm{~mm}$ based on computing constraints. To ensure the dynamic similarity of large spheres relative to actual particles in this case, compensation is provided by reducing the true density of their material from 1,300 to $100 \mathrm{~kg} / \mathrm{m}^{3}$.

3. Gravitational forces are not taken into account, since it is assumed that in the suspended state they are 
compensated by the forces of air resistance with a short duration of the processes under consideration.

4. To model the dynamic impact of seismic waves caused by an explosion, a virtual model of a mine working is used, which has a geometric and physical similarity to real-life experimental structures and is described in detail in (Kostenko et al., 2020).

\section{Mathematical model of the movement of coal dust particles under the influence of seismic waves caused by an explosion}

When describing the movement of particles impacted by seismic waves caused by the explosion, the proposed generalized equation of dynamics (Larsson, 2014) is used, which has the following form:

$$
M \ddot{U}+C \dot{U}+K U=R
$$

Where:

$M, C, K-$ the matrices of mass, damping and stiffness, respectively;

$R$ - the vector of external forces;

$\ddot{U}, \dot{U}, U-$ the particle acceleration, velocity and movement, respectively.

To approximate the kinematic parameters of particle movement, the method of finite differences according to the central implicit scheme is used, which is described by the formulas (Larsson, 2014):

$$
\begin{gathered}
\ddot{U}_{t}=\Delta t^{-2}\left(U_{t-\Delta t}-2 U_{t}+U_{t+\Delta t}\right) ; \\
\dot{U}_{t}=0.5 \Delta t^{-1}\left(-U_{t-\Delta t}+U_{t+\Delta t}\right)
\end{gathered}
$$

The contact of particles with the walls of the coal mine working and with each other is described using the method of penalty functions. A standard algorithm, applied in the software environment of the LS-DYNA computer system (Hallquist, 2006), which consists of performing such mandatory computational procedures, is used to this end.

1. There is a pair of nodes that come into contact with the interaction of particles, or a pair of nodes - the surface of the finite element (with the interaction of the particle with the wall of a working). The projection of each contact node on the tangent plane is defined as a contact point, and the distance between the contact points is the projection distance.

2. The corresponding coordinates of the contact points in the local coordinate system associated with the particle's tangent plane are determined.

3. The projection distance in a given local coordinate system related to the tangent thickness is calculated.

4. If the projection distance has a negative value, it is considered as the depth of penetration, and its val- ue determines the force acting on the contact nodes by the formula (ANSYS, 2004):

$$
f_{s}=K_{c} \cdot \delta
$$

Where:

$f_{s}$ - the contact force;

$K_{c}$ - the contact stiffness;

$\delta$ - the depth of penetration.

The contact stiffness is determined by the formula:

$$
K c=\frac{f_{s} A^{2} k}{V_{e}}
$$

Where:

$f_{s}$ - the indicator of the penalty factor;

$A$ - the area of the contact segment;

$k$ - the volume modulus of elasticity;

$V_{e}$ - the volume of the finite element with which the contact segment affiliates.

When applying a generalized approach to calculating the motion of granular systems referred to as the Discrete Element Method (DEM), the computational algorithm understands the adoption of the following basic conditions (ANSYS, 2004).

1. The particles are considered as solids with constant geometry.

2. The interaction between the particles takes place at a contact point.

3. During contact between the particles, a "soft" contact, that allows the mutual penetration of the particles, occurs. The penetration should be much less than the particle size.

4. Newton's second law is used to predict the movement of the particles, and the velocity and acceleration are constant within one integration step.

For contact interaction, the vector of the normal to the contact plane is determined by the formula (ANSYS, 2004):

$$
n_{i}=\left[x_{i}^{[B]}-x_{i}^{[A]}\right] / \sqrt{\left(x_{i}^{[B]}-x_{i}^{[A]}\right)\left(x_{i}^{[B]}-x_{i}^{[A]}\right)}
$$

Where:

$x_{i}^{[A]}, x_{i}^{[B]}$ - the vectors of coordinates of the position of points that are the centres of the corresponding particles.

Figure 2 shows the calculation schemes for calculating the contact parameters required for the calculations.

The general DEM computational algorithm includes the following calculation procedures (ANSYS, 2004).

1. The time step for the iteration is calculated.

2. The data obtained in the last step are used to initiate the movement and change the geometry of the particles in the current step.

3. The data on velocities and position of nodal points of the wall are updated.

4. The current data on the movement and geometry of the particles and the wall are updated and the state of contact interaction is identified. 


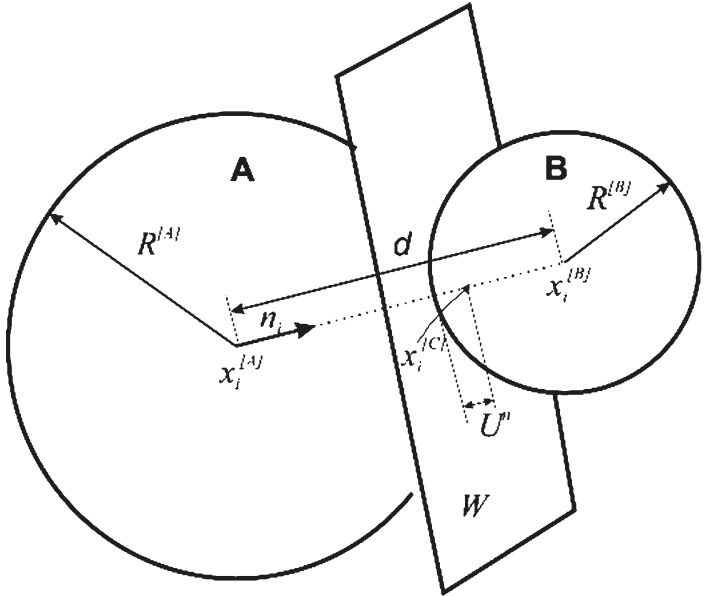

a)

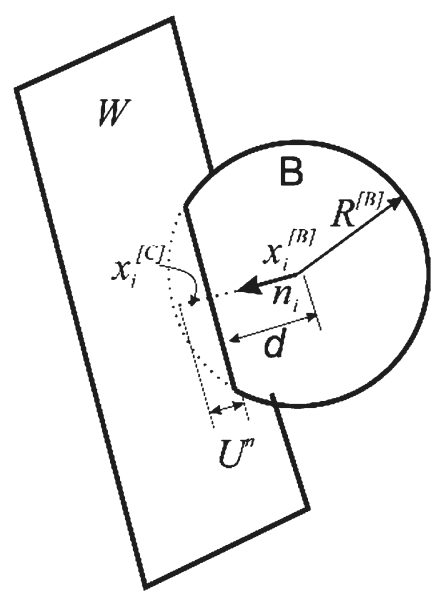

b)

Figure 2: Calculation scheme of contact interaction: $a$ - between the particles; $b$ - between the particles and walls of a working.

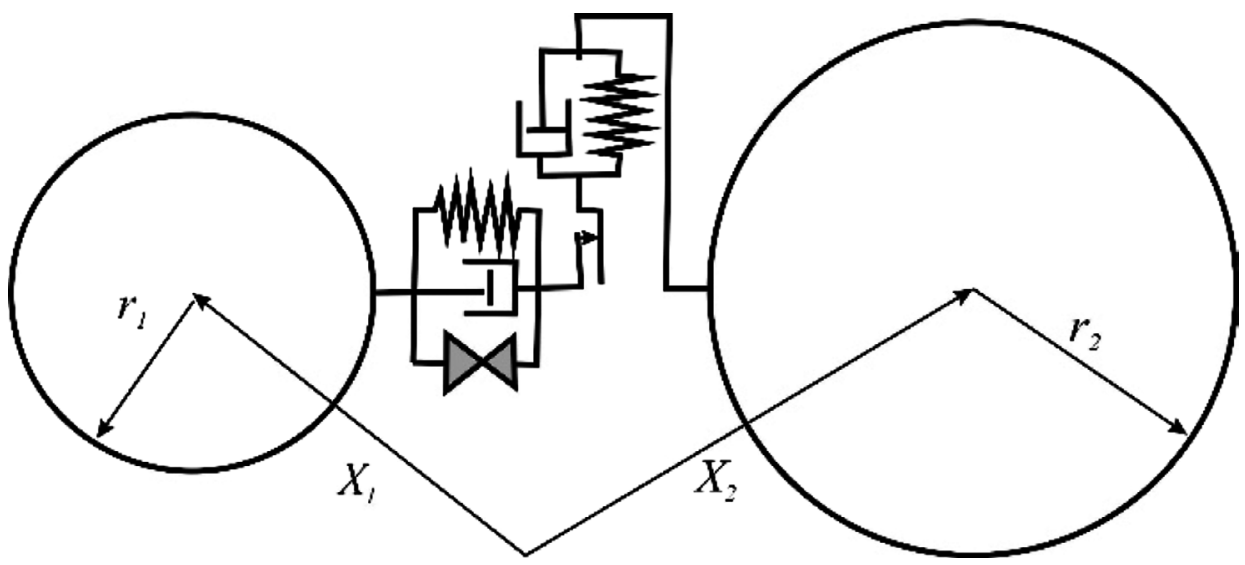

Figure 3: Calculation scheme of contact interaction between the particles, adopted for calculations in the LS-DYNA computer system.

5. The contact forces are calculated by the relative deformation at each contact point and added to the unbalanced vector of the current contact forces and the vector of internal forces is determined.

6. The accelerations at the current step at each contact point are calculated, taking into account damping.

7. The obtained values of accelerations are used to determine the velocities and positions of the particles.

8 . These procedures are repeated in the next integration step.

When performing calculations under the condition of contact interaction between the particles, the calculation scheme shown in Figure 3 is used.

The contact distance is calculated by the formula (ANSYS, 2004):

$$
d_{\text {int }}=r_{1}+r_{2}-X_{1}-X_{2}
$$

The conditions of contact interaction are shown in Figure 4.

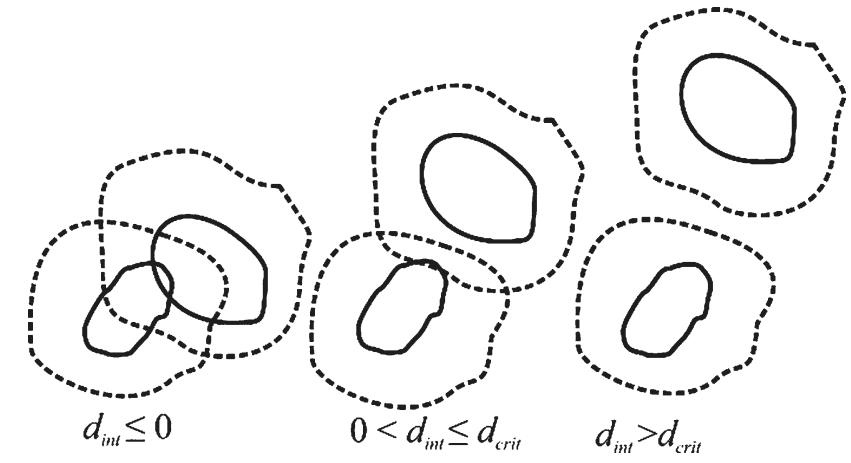

Figure 4: Conditions of contact interaction.

Using the calculation scheme shown in Figure 3, the procedure for determining the damping forces is performed using the formula (ANSYS, 2004):

Where:

$$
F_{f r}=f_{f r} F_{n}
$$

$f_{f r}$ - the coefficient of friction;

$F_{n}$ - the normal contact forces. 
When performing calculations under the condition of contact interaction between the particles and the walls, it becomes possible to use the calculation scheme shown in Figure 5.

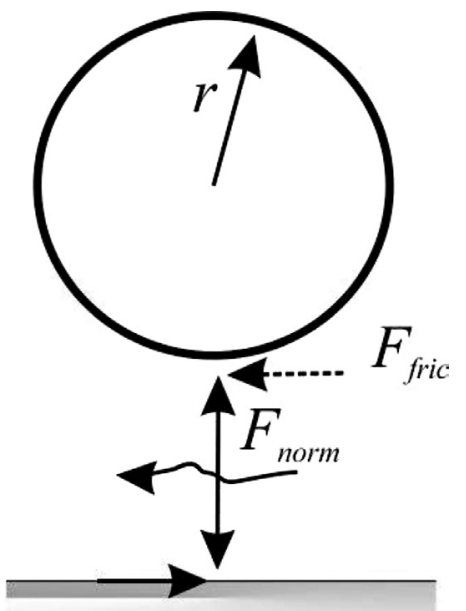

Figure 5: Calculation scheme of contact interaction between the particles and the walls, adopted for calculations in the LS-DYNA computer system.

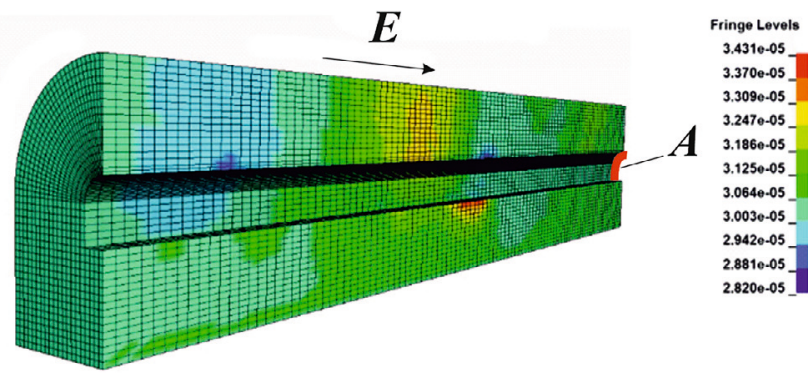

Figure 6: Distribution of the vertical component of deformation in the cross section of the experimental structure one second after the onset of the explosion:

$E$ - direction of movement of the shock front, $A$ - deposition of coal dust
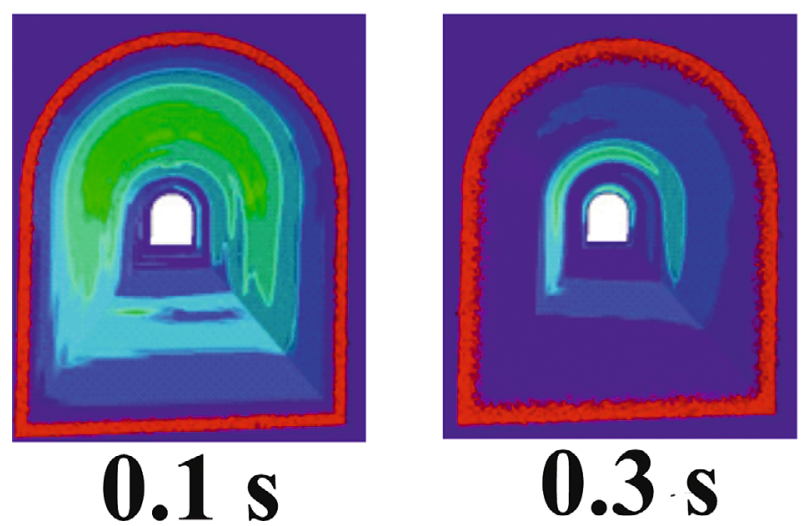

Figure 7: Dynamics of propagation during one second of seismic waves on the walls of the working and the transition of coal deposits (red) from powder to dust state
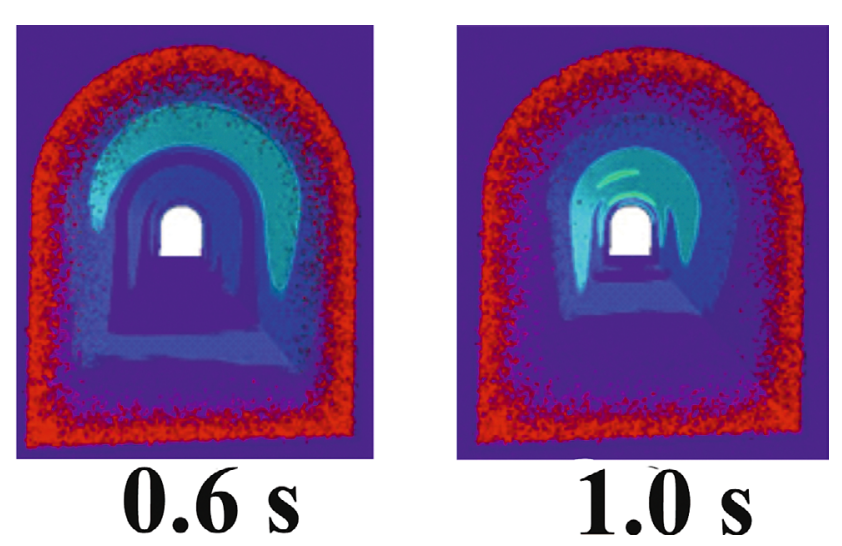

\section{Analysis and results}

In creating the model, the initial data, boundary conditions were accepted and the following assumptions were made. (Kostenko et al., 2020).

1. A working has a vaulted shape, its width is $3 \mathrm{~m}$, and its height is $4.5 \mathrm{~m}$. The thickness of the rock layer adjacent to the working is $6 \mathrm{~m}$, assuming that the reflected oscillating waves from the boundary of the layers do not significantly affect the qualitative pattern of their propagation.

2. The explosion propagates through space in turns, discretely through the cells where the explosion is initiated at a time determined by the rate of detonation propagation.

3. In each cell, there is an explosion equivalent to an explosion of $4 \mathrm{~kg}$ of TNT in the open space.

4. When modelling an explosion, its chemical and gas-dynamic nature are not taken into account, but its result is considered in the form of a corresponding pressure curve on the walls of the working.

5. A material with average mechanical characteristics close to sedimentary rocks of coal deposits is accepted as a rock material adjacent to the working walls.

6. The rock material is homogeneous, isotropic and solid without cavities or cracks.

Before the explosion, there are no deformations in the body of the experimental structure, coal deposits in the form of dust are at steady state. The hypocentre of the explosion moves along the working; part of the explosive energy propagates in the surrounding environment in the form of seismic waves, leading to deformation of the rocks in the whole volume (see Figure 6).

Wave deformations of a variable sign move along the outline of working, leading to oscillations of its walls and the dust on the walls. This leads to a gradual, as the front of the explosion moves, throwing of coal particles and loosening the dust layer in the interval of 0 to $0.5 \mathrm{~s}$. Subsequently, the dust is raised into the air, and after $1 \mathrm{~s}$ 


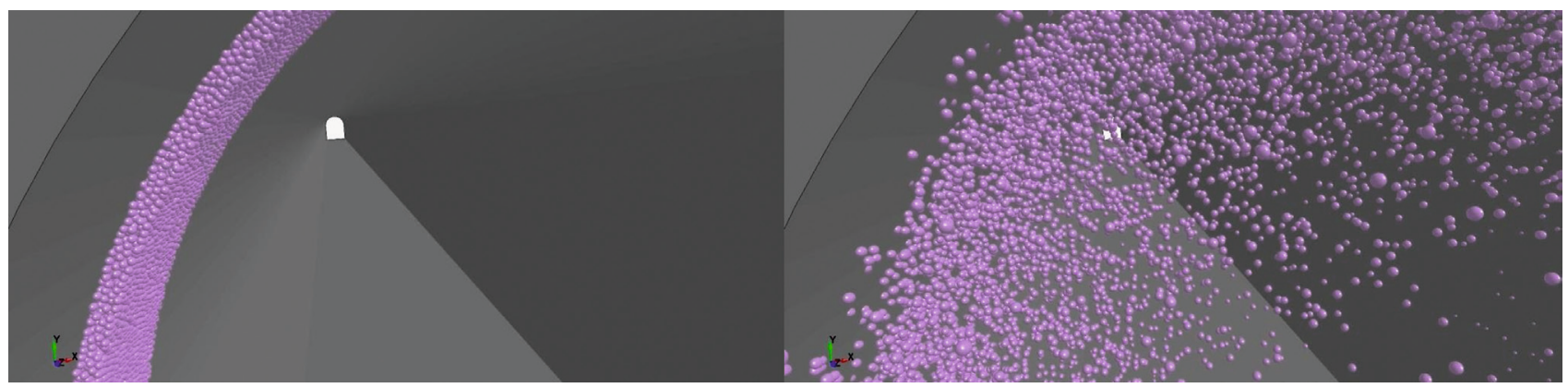

a)

b)

Figure 8: Formation of a dust cloud in a working:

$a$ - fragment of the working wall with deposits of coal dust before the explosion, $b$ - after one second

from the beginning of the explosion, almost all the dust hangs in the air forming a dust cloud (see Figure 7).

Analysis of a more detailed fragment of the coal dustcoated section shows that the deposited layer entirely transits to a moving state. Within one second, the layer of coal dust entirely transited into a state of air suspension, forming a cloud with a total thickness of at least 80 $\mathrm{cm}$ (see Figure 8). The concentration of dust decreases from the walls to the centre.

Due to the short time of the described process, the modelling does not take into account the influence of gravity, but with an increasing duration of seismic oscillations, it can increase the size of the cloud from the vault and walls. Thus, even before the shock front approaches, coal dust is formed in the cavity of the working, which fills a part of the section, with a part of the dust cloud having a concentration of fuel that is able to maintain combustion in the detonation state. The appearance of coal dust shortly before the impact of the shock wave was noted by victims of several accidents, including at the Zasyadko Mine (Donetsk, Ukraine) in 2007, as reported in the accident investigation.

\section{Discussion}

The modelling confirmed, once again, that the velocity of the blast front is much lower than the velocity of seismic waves; they reach the location of powder-like dust deposits earlier. Within a few hundredths of a second, the seismic waves reach the far end of the experimental structure. Due to the action of seismic waves, coal deposits loosen, rise from the walls and floors of the working and fastening elements. A cloud of coal particles suspended in the air, an aerosol, is formed. The generalization of the obtained results with the given known data allows for the improvement of the scenario of coal dust explosion development. When the shock front approaches, the aerosol is rapidly compressed, just like in a diesel engine (Romanchenko et al., 2020). A detonation combustion of coal and gas components of the cloud occurs with the release of a powerful radiant and convection energy, with a sharp increase in the volume of hot gases. This is accompanied by the vortex movements of the coal particles, remaining free-lying on the surfaces, and the suspended ones. Sharp compression and heating of coal particles is accompanied by the release of volatile combustible components, which intensifies the combustion process. The authors of this paper did not set the task of revealing the physical and chemical transformations of coal as a result of the explosion, but the data obtained allowed for the clarification of certain details of the initial dynamics of the described process.

The amount of energy released in this case is sufficient for the formation of a high pressure front before the fire front, and the ignition of the next section of the working covered with powder and dust. Also, a part of the energy is spent on the excitation of seismic waves in the surrounding rocks and the subsequent transfer of powder clusters to dust clouds.

A detonation combustion continues in the fire front with a sufficient content of coal dust, but there is a lack of oxygen. Under the influence of high temperature, the coal cokes. The heated particles, picked up by vortices, move along with the front, and some of them forcibly fall into the opposite surfaces of the fasteners, equipment and walls, forming a layer of the so-called "coke breeze".

The obtained data are largely idealized due to the fact that the virtual experimental structure is significantly different from the actual mine working. First of all, the model provides for a reflection of seismic waves from the external walls and ends of a construction, which distorts the distribution of oscillations of the working walls to some extent. However, the qualitative, and to some extent quantitative, pattern of the transition of coal particles from powder state to dust clouds remains reliable. To clarify the quantitative parameters, it is advisable to continue research in real-life conditions of the underground mine workings.

\section{Conclusions}

The qualitative and quantitative behaviour of a layer of coal dust in the process of oscillation of the working 
walls under the influence of seismic waves during one second was described.

The stage of dynamic loosening of the powder is supplemented by the initial period of the mechanism of explosion development, when there are no combustible concentrations of gas or coal traces in the air composition of the mine working before the accident.

It is established that under the seismic influence at a distance of about $50 \mathrm{~m}$ from the hypocentre of the explosion, a layer of powder-like dispersed coal rises into the air forming a dust cloud, which is the initiator of further continuous development of the explosion spreading in a network of mine workings.

Disclosure of the mechanism of the formation of an explosive dust environment allows for the substantiation of the improved ways of prevention and localization of explosions in coal mine workings. For example, it is expedient to increase the speed and reliability of operation of explosive suppressors or similar means by registering seismic waves in a rock mass.

\section{References}

Ajrash, M. J., Zanganeh, J., Moghtaderi, B. (2016): Methanecoal dust hybrid fuel explosion properties in a large scale cylindrical explosion chamber. Journal of Loss Prevention in the Process Industries, 40, 317-328. doi:10.1016/j. jlp.2016.01.009.

ANSYS (2004): ANSYS Structural Analysis Guide, ANSYS, Inc.: Canonsburg, PA, 402p.

Cherdantsev, S., Filatov, Y., Shlapakov, P. (2020): Modes of diffusion combustion of fine dust-gas-air mixtures in the atmosphere of mine workings. Ugol, 2, 27-32. doi: 10.18796/0041-5790-2020-2-27-32.

Cherdantsev, S., Un, L., Filatov, Y., Shlapakov, P. (2018): Determination of critical ignition temperature of micro-heterogeneous dust/gas-air mixtures in mines. Mining Informational and Analytical Bulletin, 1, 117-125. doi:10.25018 /0236-1493-2018-1-0-117-125.

Demir, S., Calavay, A. R., Akkerman, V. (2017): Influence of gas compressibility on a burning accident in a mining passage. Combustion Theory and Modelling, 1-21. doi:10.10 80/13647830.2017.1403654.

Hallquist, J.O. (2006): LS-DYNA Theory Manual, Livermore Software Technology Corporation, California, USA, 680p.

Jing, G., Liu, C., Duan, X., Guo, S., Zhang, S., Wu, Y., Shao, H. (2019): Experimental study on gas-coal dust coupling explosion in semi-closed pipeline. Meitan Xuebao/Journal of the China Coal Society, 44, 157-163. doi:10.13225/j. cnki.jccs.2019.0052.

Kostenko, V., Liashok, Ya., Zavialova, O., Pozdieiev, S., Kostenko, T. (2020): The deformation dynamics of the experimental adit's material during a coal dust explosion. EasternEuropean Journal of Enterprise Technologies, 4, 7 (106), 54-62. https://doi.org/10.15587/1729-4061.2020.209409/.
Kostenko, V., Zavialova, O., Pozdieiev, S., Kostenko, T., Vinyukov, A. (2021): Substantiation of design parameters of coal dust explosion containment system. News of the National Academy of Sciences of the Republic of Kazakhstan, Series of Geology and Technical Sciences, 3, 447, 72-76. DOI:10.32014/2021.2518-170X.65.

Larsson, S. (2014): Characterization and modeling of rock impact on steel plates. Master's Thesis. Lulea University of Technology Department of Engineering Sciences and Mathematics Division of Mechanics of Solid Materials, $77 \mathrm{p}$.

Li, R. (2018): Minimum explosive concentration of coal dust cloud in the coexistence of gas and coal dust. Baozha Yu Chongji/Explosion and Shock Waves, 38, 4, 913-917. doi:10.11883/bzycj-2016-0331.

Mishra, D. P., Azam, S. (2018): Experimental investigation on effects of particle size, dust concentration and dust-dispersion-air pressure on minimum ignition temperature and combustion process of coal dust clouds in a G-G furnace. Fuel, 227, 424-433. doi:10.1016/j.fuel.2018.04.122.

Moradi, H., Sereshki, F., Ataei, M. and Nazari, M. (2019): Evaluation of the effect of the moisture content of coal dust on the prediction of the coal dust explosion index. Rudarsko-geološko-naftni zbornik (The Mining-Geological-Petroleum Bulletin), 35, 1, 37-47. DOI: 10.17794/ rgn.2020.1.4

Pinaev, A. V., Pinaev, P. A. (2020): Combustion and detonation waves in gas mixtures of $\mathrm{CH}_{4} / \mathrm{Air}, \mathrm{CH}_{4} / \mathrm{O}_{2}$, and $\mathrm{O}_{2} / \mathrm{Coal}$ dust. Combustion, Exlosion and Shock Waves, 56, 6, 670681. doi:10.1134/S0010508220060064.

Prodan, M., Ghicioi, E., Nălboc, I., Szollosi-Mota, A. (2017): Minimum ignition temperature of dust cloud analysis for safe industrial processes. Quality - Access to Success, 18, 146-150.

Romanchenko, S. B., Trubitsyn, A. A. (2019) Analysis microscopic method of dust participation degree in explosions. Industrial safety, 3, 6-16.

Vasil'ev, A. A. (2020): Evaluation of the suppression conditions for combustion and detonation waves. Combustion, Explosion and Shock Waves, 56, 5, 527-532. doi:10.1134/ S0010508220050032.

Vasil'ev, A. A., Pinaev, A. V., Trubitsyn, A. A., Grachev, A. Y., Trotsyuk, A. V., Fomin, P. A., Trilis, A. V. (2017): What is burning in coal mines: Methane or coal dust? Combustion, Explosion and Shock Waves, 53, 1, 8-14. doi:10.1134/ S0010508217010026.

Wang, Y., Qi, Y., Gan, X., Pei, B., Wen, X., Ji, W. (2020): Influences of coal dust components on the explosibility of hybrid mixtures of methane and coal dust. Journal of Loss Prevention in the Process Industries, 67. doi:10.1016/j. jlp.2020.104222.

Zhikharev, S., Rodionov, V., Pikhkonen, L. (2018): Innovative methods for investigating technological properties and explosion/fi re risk data of coal dust. Gornyi Zhurnal, 6, 4549. doi:10.17580/gzh.2018.06.09. 


\section{SAŽETAK}

\section{Mehanizam razvoja kontinuirane eksplozije ugljene prašine u mreži rudarskih radova}

Cilj je rada otkriti mehanizam stvaranja uvjeta za kontinuiranu eksploziju ugljene prašine prijenosom seizmičke energije na ugljenu prašinu koja se nalazi duž opsega čela. Programski paket ANSYS korišten je za modeliranje kretanja čestica ugljene prašine u zraku pod utjecajem seizmičkih valova uzrokovanih djelovanjem eksplozije. Modeliranjem je potvrđeno da se seizmički valovi, izazvani eksplozijom, šire u stijenskoj masi većom brzinom od zvučnoga udarnog vala ispred čela. Opisano je kvalitativno i kvantitativno ponašanje sloja ugljene prašine u procesu osciliranja stijenki čela pod utjecajem seizmičkih valova tijekom jedne sekunde. Faza dinamičkoga rastresanja praha potpomognuta je početnim razdobljem mehanizma razvoja eksplozije, kada nema zapaljivih koncentracija plina ili ugljena u sastavu zraka rudnika prije nesreće. Utvrđeno je da se pod seizmičkim utjecajem na udaljenosti od oko $50 \mathrm{~m}$ od hipocentra eksplozije sloj praha raspršenoga ugljena diže u zrak stvarajući oblak prašine, koji je pokretač daljnjega kontinuiranog razvoja eksplozije šireći se u mreži rudarskih radova.

\section{Ključne riječi:}

eksplozija, ugljena prašina, modeliranje, seizmički valovi, rudarski radovi

\section{Author's contribution}

Viktor Kostenko (doctor of technical sciences, professor) initialized the idea, developed a methodological approach, managed the whole process and supervised it from the beginning to the end. Olena Zavialova ( $\mathrm{PhD}$, associate professor) reviewed literary sources, processed and analyzed the experimental results. Serhii Pozdieiev (doctor of technical sciences, professor) created a 3D model of a fragment of mining, and modelled explosion scenarios. Tetiana Kostenko (doctor of technical sciences, professor) participated in all stages of work, submitted and reviewed the paper, completed a review of the literature, and analyzed the experimental results. Viktor Hvozd (PhD, professor) set the initial data for modelling, and processed the modelling results. 